\title{
Physico-chemical and mineral analysis of composts fortified with NPK fertilizer, ammonium chloride and kaolin
}

\author{
Margaret Ojone Ogundare ${ }^{1,2^{\star}}$, Labunmi Lajide $^{1}$ \\ ${ }^{1}$ Department of Chemistry, Federal University of Technology, Akure, Nigeria; ${ }^{*}$ Corresponding Author: ojoneachimugu@yahoo.com \\ ${ }^{2}$ Prototype Engineering Development Institute, Ilesa, Nigeria
}

Received 20 December 2012; revised 20 February 2013; accepted 1 March 2013

Copyright (C) 2013 Margaret Ojone Ogundare, Labunmi Lajide This is an open access article distributed under the Creative Commons Attribution License, which permits unrestricted use, distribution, and reproduction in any medium, provided the original work is properly cited.

\section{ABSTRACT}

This work presents the physicochemical and mineral analysis of compost samples made from waste materials of cassava, vegetable, banana, orange, and cow dung fortified each with $100 \mathrm{~g}$ of NPK, $100 \mathrm{~g}$ of kaolin and $100 \mathrm{~g}$ of ammonium chloride. Microbial analysis of the fresh compost samples revealed that the unfortified compost possesses more microbial load than the fortified samples. The physicochemical analysis showed that the kaolin fortified compost (KFC) has the highest ash content and phosphorus content while the unfortified compost (UC) contains the highest organic matter. All the compost samples have little nitrogen when compared with NPK chemical fertilizer. However, the fortification with kaolin, NPK and ammonium chloride increased the percentage of nitrogen over that of the unfortified compost by $\mathbf{3 8 . 8 \%}$, $56.23 \%$, and $71.17 \%$ respectively. The fortification with kaolin, NPK, and ammonium chloride also increased the phosphorus content over that of the unfortified by $56.31 \%, 53.21 \%$ and $36.75 \%$, respectively. The result of the mineral content showed that the fortification with NPK and ammonium chloride increased the magnesium content of the compost sample while fortification with kaolin increases the magnesium and calcium content. The nitrate and sulfate contents are reduced by the fortification with kaolin, NPK and ammonium chloride.

Keywords: Compost; Fortification; Microbial; Mineral; Physicochemical

\section{INTRODUCTION}

With the advancement of industrial age resulting to farmlands been taken over, there is need to increase and maximize the soil life of the available farmlands. This is achievable by humidification of soil instead of adding chemical fertility. Also with the increasing problem of waste disposal, composting of waste material converts it to soil enriching product useful in maintaining the structure and fertility of agricultural land and at the same time leading to a cleaner environment [1]. Organic resources are often proposed as alternate to commercial mineral fertilizer [2]. Composting begins the process of breaking down organic material into what will eventually become humus in the soil. Agricultural wastes are essentially of plant origin and therefore contain the entire nutrients essential for plant growth [3]. Plant and animal wastes are freely available on most organic holdings and these can be composted for the supply of nutritious or- ganic matter to be returned to the soil. Generally, organic fertilizers contain relatively low concentrations of the actual plant nutrients, and are not immediately available for plant utilization. Hence, the fortification of organic wastes and their composts as a source of organic nutrients are imperative for sustainable agriculture. Also the fortification of compost with chemical fertilizer enhances agronomic effectiveness of both the organic matter and nutrients by reducing the amount of fertilizer and improving the quality of compost. Many workers have studied the beneficial effects of organic wastes as fertilizers and soil amendments and its fortification to enhance the nutrient content. According to Neemat and Khaled [4], the amendment of soil with biofortified compost increased the proliferation of the total bacteria in the rhizosphere of wheat plants compared with compost. Compost enhanced both spore production and the 
percentage of mycorrhizal root colonization of wheat plants as compared with the NPK treatment, while biofortified compost highly increased both the mycorrhizal spore numbers and the percentage of mycorrhizal root colonization when supplementing $60 \%$ mineral fertilizer as compared with other treatments. Also Nitrogen and L-Trytophan enriched compost significantly promoted growth and yield both of wheat and maize crops compared with control [5]. Daramola et al., [6] also reported that composted maize cob fortified with mineral-Nitrogen gives increased plant height and greater fresh weight of root and shoot in maize and also it was reported that highest growth parameters for Celosia plant were recorded with the application of $375 \mathrm{~kg} / \mathrm{ha}$ NPK which was not significantly different from what was observed with the application of $3 \mathrm{t} / \mathrm{ha}$ cassava peel compost (CPC) or that with the application of $2 \mathrm{t} / \mathrm{ha} \mathrm{CPC}+187.5 \mathrm{~kg} / \mathrm{ha} \mathrm{NPK} \mathrm{[2].}$

The main objective of this study is to determine the difference in the physicochemical properties and mineral contents in the unfortified compost and the fortified composts samples and also as compared with that of the chemical fertilizer NPK (15:15:15).

\section{MATERIALS AND METHODS}

\subsection{Methodology}

Composting materials consisted of cassava waste, banana peels, orange peels, vegetables (Amaranthus) waste and fresh cow dung to activate the pile. $1100 \mathrm{~g}, 260 \mathrm{~g}$, $580 \mathrm{~g}, 880 \mathrm{~g}$, and $700 \mathrm{~g}$ were weighed respectively and mixed to make a heap. The composting was carried out in buckets kept in an enclosed store room. Three sets of three buckets were heaped with the pile, each containing the mixture mentioned above. A set was treated with100 $\mathrm{g}$ of NPK fertilizer, another with $100 \mathrm{~g}$ of kaolin and the third with $100 \mathrm{~g}$ of ammonium chloride. Another heap was prepared to serve as control without treatment with any of the fortifying material. Each heap of the mixture was watered and turned every forth night until decomposition was completed. At maturity, the wet samples from each heap mixture were taken for microbial analysis. The samples were then air dried, weighed and ground using a ball mill. The ground (powdered) compost samples were sieved using mesh of three different sizes: $150 \mu \mathrm{m}, 212$ $\mu \mathrm{m}$ and $425 \mu \mathrm{m}$ and taken for chemical analysis. Analyzed parameters were ash, nitrogen and organic matter contents, phosphorus, sulfate and nitrate content. Elemental analysis of potassium, nickel, zinc, cobalt, copper, lead, iron, magnesium, sodium and calcium was also carried out.

\subsection{Determination of Physicochemical Parameters}

Ash and organic matter contents were determined using furnace ashing at $550^{\circ} \mathrm{C}$ and lost on ignition methods respectively as described in official methods of analysis [7]. Nitrogen content was determined by Kjedahl method [8].

\subsection{Colorimetric Analysis}

Nitrate was extracted from the samples using $100 \mathrm{ml}$ of $2 \mathrm{M} \mathrm{KCl}$ [9]. Set of standard solutions were prepared by adding $1 \mathrm{ml}$ of $5 \%$ salicylic acid and $10 \mathrm{ml}$ of $4 \mathrm{M}$ sodium hydroxide solution. The percentage transmittance was taken at $410 \mathrm{~nm}$ wavelength on a B \& L 70 electro colorimeter. Phosphorus content was determined using the vanadomolybdate method as described in the official methods of analysis [7]. The percentage transmittance of the set of standard solutions was determined at $400 \mathrm{~nm}$ wavelength. Sulfate content was determined using the turbid metric method as described in official methods of analysis [7]. Set of standards solutions were prepared and the $\%$ transmittance was determined at $420 \mathrm{~nm}$ wavelength on the colorimeter. A working curve was plotted using each set of the readings. Concentrations in ppm from each set of the determinations are calculated thus:

$\mathrm{ppm}$ concentration in solution $=\mathrm{R}^{*} \mathrm{~V}^{*} \mathrm{Df} /$ weight of sample used.

Where: $\mathrm{R}=$ result from extrapolation on curve, $\mathrm{V}=$ volume of sample solution, $\mathrm{Df}=$ dilution factor.

\section{ELEMENTAL ANALYSIS}

$2 \mathrm{~g}$ of each compost sample and that of the fertilizer were ashed in a muffle furnace using the AOAC [7] method; the ash of each of the sample was cooled and then dissolved with 3:1 ratio of $0.1 \mathrm{MHCl}$ and $\mathrm{HNO}_{3}$ solution. Atomic absorption spectrophotometer model 210, Buck Scientific at Chemistry Department, Federal University of Technology, Akure was used for the analysis of the metals of interest.

\section{RESULTS AND DISCUSSION}

\subsection{Microbial Screening}

The microbial screening carried out on the compost samples showed that the colony forming units (cfu) of microorganisms in the unfortified compost (UC) is very much higher than that in any of the fortified compost (Figure 1). The total viable count of microorganisms in the UC is $142 \times 10^{4} \mathrm{cfu} / \mathrm{g}$. The total viable count of microorganisms in the fortified samples are $256 \mathrm{cfu} / \mathrm{g}, 280$ cfu/g and $200 \mathrm{cfu} / \mathrm{g}$ in KFC1, KFC2, KFC3 respectively, $78 \mathrm{cfu} / \mathrm{g}, 50 \mathrm{cfu} / \mathrm{g}$, and $35 \mathrm{cfu} / \mathrm{g}$ in NFC1, NFC2, NFC3 respectively and $67 \mathrm{cfu} / \mathrm{g}, 62 \mathrm{cfu} / \mathrm{g}$, and $59 \mathrm{cfu} / \mathrm{g}$ in $\mathrm{AFC} 1, \mathrm{AFC} 2, \mathrm{AFC} 3$ respectively. This shows that the presence of the fortifying material during composting does not allow the thriving of the microorganism. Also, screening the compost samples for associated microor- 


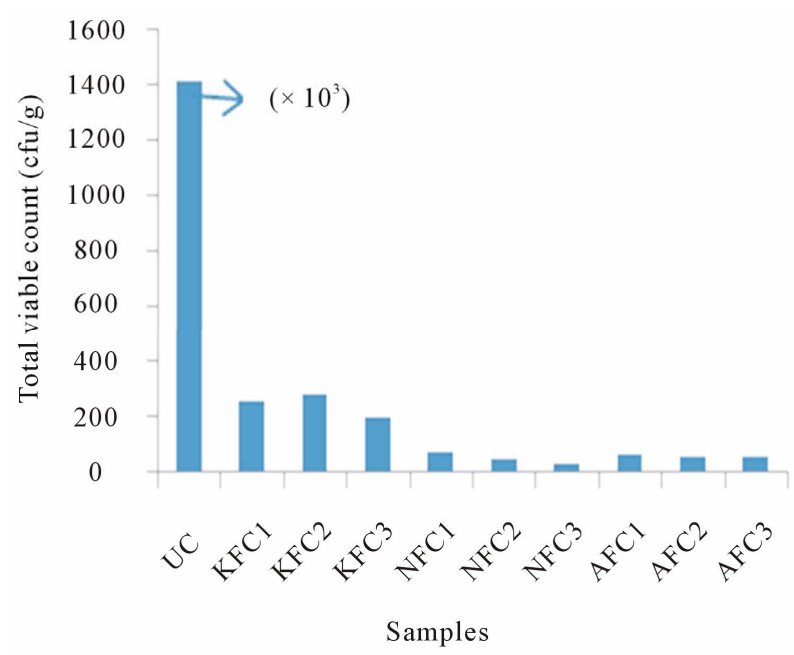

Figure 1. Graph of total viable count of microorganisms against samples.

ganisms, the bacterial Bacillus subtilis was identified in all the compost samples, the fungi, Erwinia herbicola, Articulospors infalata, and Tricoderma virde were identified in UC sample, and few other fungi were also identified in some of the compost samples as shown in Table 1.

KFC: Kaolin fortified compost, NFC: NPK fortified compost, AFC: Ammonium chloride fortified compost.

\section{THE PHYSICO CHEMICAL PROPERTIES}

The fortified compost samples all have higher value of the ash content than the UC, with KFC having the highest ash content of $60.25 \pm 0.58 \%$ (Table 2) which indicates high mineral content in the fortified compost samples. The importance of ash content is that it gives an idea of amount of mineral elements present and the content of the organic matter in a sample [10]. This value is much higher than that of the UC which is $31.96 \pm 0.07 \%$ and of the chemical fertilizer (NPK) which is $47.58 \pm$ $0.52 \%$. This means that the ground silicate rock will re-mineralize degraded soils. The organic matter content of the UC is the highest (Table 2). These results indicate that the fortifying materials reduce the organic matter content of the compost during the composting process and therefore should be blended with finished compost rather than being composted with the waste materials. This is to allow the effect of the increased mineral content and also maintaining the high organic matter content of the compost. As one of the most important benefits of using compost is the addition of organic matter. Organic matter provides nutrition for soil life and increases stability of the soil. Also mycorrhizal fungi which make other nutrients more available to plants thrive in soil where the organic matter content is high [11].

\section{PERCENTAGE NITROGEN, PHOSPHORUS, NITRATE ACID SULPHATE CONTENT}

The percentage nitrogen content of the compost samples (both fortified and unfortified) are very low compared with the $\%$ nitrogen content of the chemical fertilizer (NPK 15, 15:15) 79:35\%. This can be explained by the fact that during the composting process; nitrogen has been used up for the decay process. Hence, to increase the nitrogen content of the compost more of the nitrogen based waste should be used for composting [1]. Although both fortifications increased the percentage nitrogen content over the unfortified compost. The phosphorus content result (Table 3) showed that fortification with kaolin gives high content of phosphorus which is one of the primary macro plant nutrient compared with the chemical fertilizer and the unfortified compost sample. The nitrate and sulfate contents in the fortified samples are reduced by the fortifications as compared with that in UC sample, shown in Figures 2 and $\mathbf{3}$ respectively. This reduction in the nitrate and sulfate content could be as a result of the reduced colony forming unit of microorganism in the fortified compost. Microorganisms break down soluble nitrogen to nitrate in the process of nitrification [12]. Also sulfur relies on soil microbes to be converted into plant usable form which is in the form of calcium, potassium or magnesium sulfate [12]. Hence the reduction in both sulfate and nitrate content is attributed to the reduction in the colony forming units of the microorganisms in the fortified compost samples.

\section{MINERAL ANALYSIS}

The result showed that both compost samples have a high content of the plant macro nutrients, $\mathrm{K}, \mathrm{Ca}$, and $\mathrm{Mg}$ as shown in Tables 4(a)-(c) below. Although the values for $\mathrm{Ca}$ and $\mathrm{K}$ are much lower compared with those for the chemical fertilizer, this supports the statement that organic manure even though have the ability of supplying both the required macro and micro plant nutrients but supplies them in low quantities [13]. Mg content is increased in both samples. The micro nutrients $\mathrm{Cu}, \mathrm{Fe}, \mathrm{Mn}$, and $\mathrm{Zn}$ are presented in low quantities in both the compost samples and the chemical fertilizer, although the value of $\mathrm{Mn}$ is higher in the compost samples than in the chemical fertilizer.

The fortification with kaolin, ammonium chloride and NPK increased macro nutrients like nitrogen, phosphorus and magnesium which are very essential to plant growth. This will be most effective if the fortifying materials are blended with the finished compost. Also the high organic matter content of UC shows that the waste materials are good source of organic fertilizer. From the results, it is 


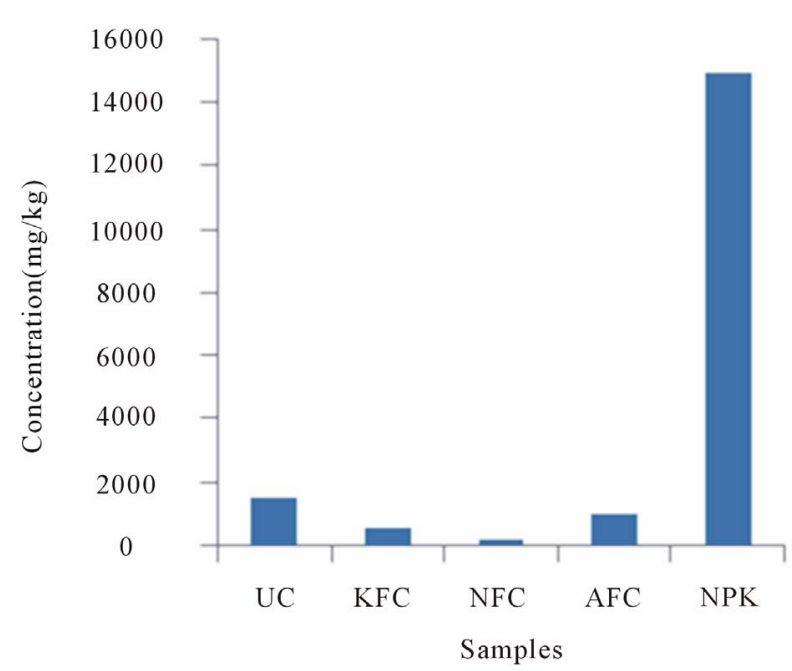

(a)

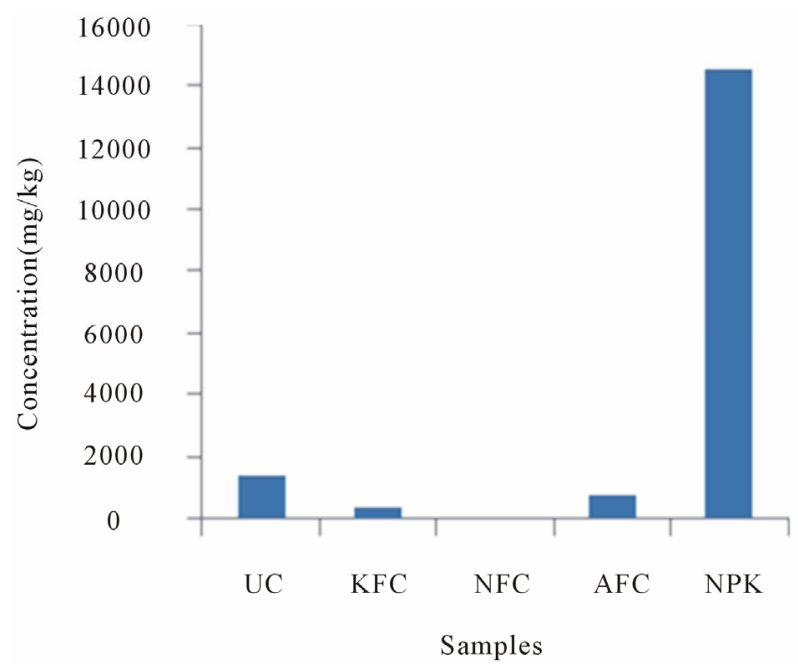

(b)

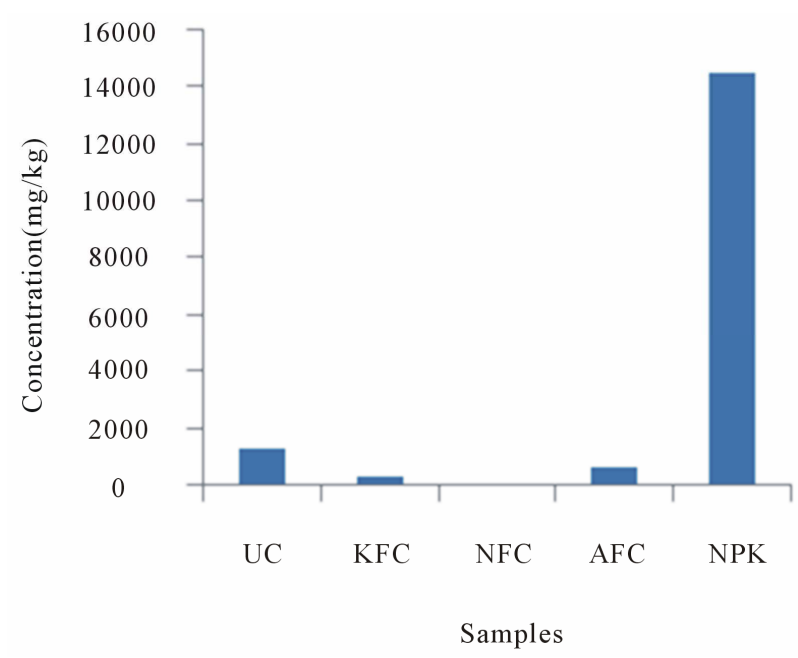

(c)

Figure 2. Graphs of the nitrate content in the compost samples for the mesh sizes $150 \mu \mathrm{m}, 212 \mu \mathrm{m}$ and $425 \mu \mathrm{m}$, respectively. (a) $150 \mu \mathrm{m}$; (b) $212 \mu \mathrm{m}$; (c) $425 \mu \mathrm{m}$.

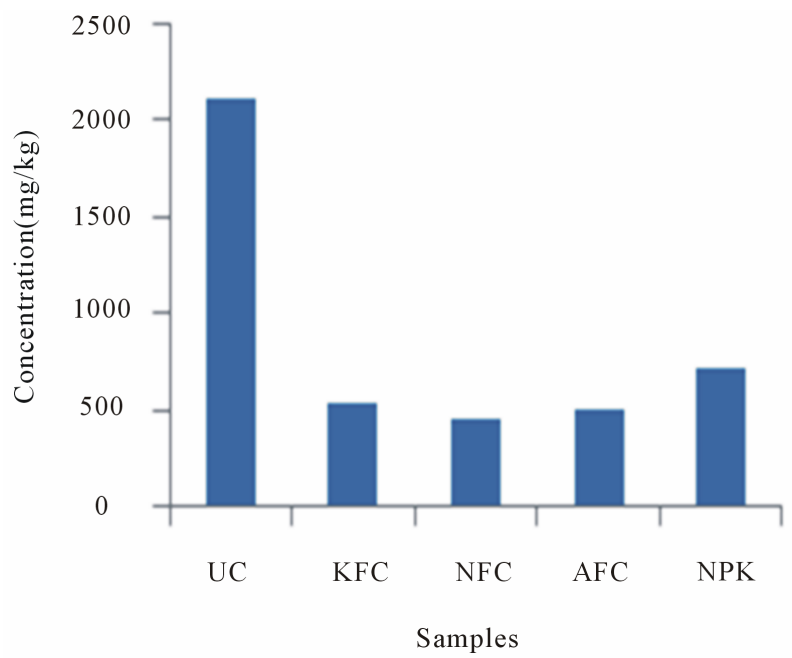

(a)

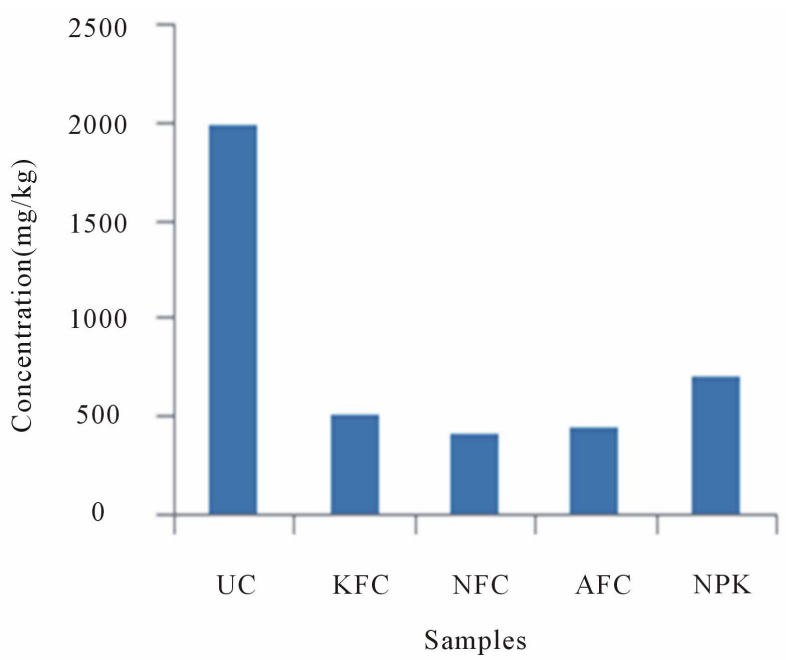

(b)

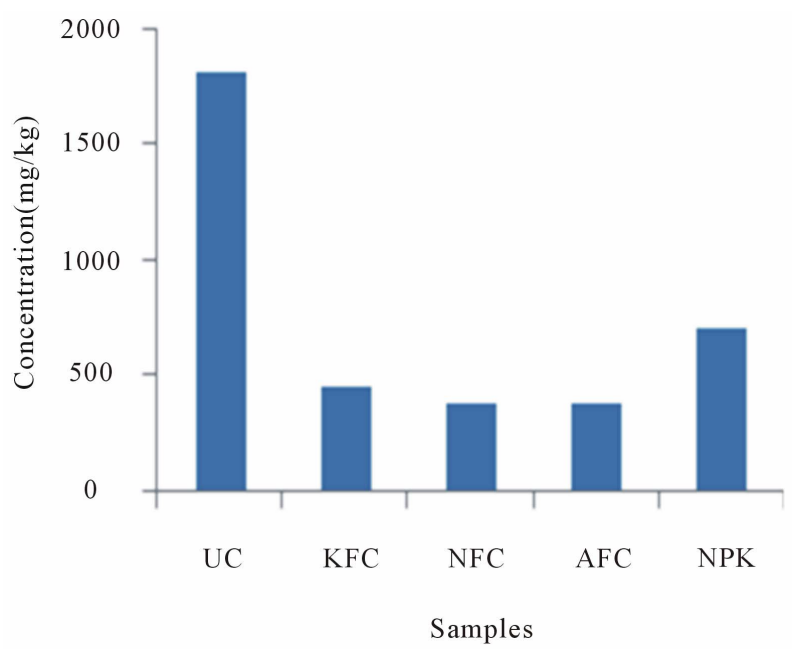

(c)

Figure 3. Graphs of the sulfate content in the compost samples for the mesh sizes $150 \mu \mathrm{m}, 212 \mu \mathrm{m}$ and $425 \mu \mathrm{m}$, respectively. (a) $150 \mu \mathrm{m}$; (b) $212 \mu \mathrm{m}$; (c) $425 \mu \mathrm{m}$. 
Table 1. Microorganisms associated with the compost samples.

\begin{tabular}{|c|c|c|c|c|c|c|c|c|c|c|}
\hline Microorganisms & $\mathrm{UC}$ & $\mathrm{KFC} 1$ & $\mathrm{KFC} 2$ & $\mathrm{KFC} 3$ & NFC1 & $\mathrm{NFC} 2$ & NFC3 & $\mathrm{AFC} 1$ & $\mathrm{AFC} 2$ & $\mathrm{AFC} 3$ \\
\hline $\begin{array}{c}\text { Bacteria } \\
\text { Bacillus subtilis }\end{array}$ & + & + & + & + & + & + & + & + & + & + \\
\hline $\begin{array}{l}\text { Fungi } \\
\text { A. flavus }\end{array}$ & - & - & - & - & - & - & + & - & - & - \\
\hline A. fumgatus & - & - & - & - & - & - & - & - & - & + \\
\hline A. niger & - & + & + & - & + & - & - & - & - & - \\
\hline A. rapens & - & - & + & + & + & - & - & - & - & - \\
\hline Penicillium italicum & - & - & - & + & - & - & - & + & - & - \\
\hline Radiomyces embreci & - & - & - & - & - & - & - & - & + & - \\
\hline Gliocladium deliquesscus & - & - & - & - & - & + & - & - & - & - \\
\hline Harpographium fasciculatum & - & - & - & + & - & - & - & - & - & - \\
\hline Erwinia herbicola & + & - & - & - & - & - & - & - & - & - \\
\hline Articulospora infalata & + & - & - & - & - & - & - & - & - & - \\
\hline Trichoederma virde & + & - & - & - & - & - & - & - & - & - \\
\hline
\end{tabular}

Key: +: present; -: absent; A: Aspergillus.

Table 2. The ash content, moisture content and organic matter content of the compost samples.

\begin{tabular}{|c|c|c|c|c|c|c|c|c|c|}
\hline $\begin{array}{l}\text { Mesh size } \\
\text { Samples }\end{array}$ & & $150 \mu \mathrm{m}$ & & & $212 \mu \mathrm{m}$ & & & $425 \mu \mathrm{m}$ & \\
\hline Sample & $\mathrm{AC}$ & $\mathrm{MC}$ & OM & $\mathrm{AC}$ & $\mathrm{MC}$ & OM & $\mathrm{AC}$ & $\mathrm{MC}$ & OM \\
\hline $\mathrm{UC}$ & $31.96^{\mathrm{b}} \pm 0.07$ & $31.96^{\mathrm{h}} \pm 0.07$ & $69.26^{\mathrm{h}} \pm 0.58$ & $30.74^{\mathrm{a}} \pm 0.58$ & $30.74^{\mathrm{g}} \pm 0.58$ & $68.04^{\mathrm{g}} \pm 0.07$ & $27.97^{\mathrm{c}} \pm 0.05$ & $27.98^{\mathrm{h}} \pm 0.05$ & $72.02^{\mathrm{f}} \pm 0.05$ \\
\hline KFC2 & $56.99^{\mathrm{h}} \pm 0.63$ & $13.08^{\mathrm{d}} \pm 0.01$ & $43.01^{b} \pm 0.63$ & $47.47^{\mathrm{g}} \pm 0.07$ & $12.80^{\mathrm{d}} \pm 0.06$ & $52.53^{\mathrm{b}} \pm 0.07$ & $37.29^{\mathrm{h}} \pm 0.36$ & $12.64^{\mathrm{c}} \pm 0.01$ & $62.72^{c} \pm 0.37$ \\
\hline KFC3 & $55.08^{\mathrm{j}} \pm 0.57$ & $11.34^{\mathrm{c}} \pm 0.01$ & $44.92^{c} \pm 0.57$ & $42.19^{\mathrm{e}} \pm 0.07$ & $11.18^{\mathrm{c}} \pm 0.01$ & $57.80^{\mathrm{d}} \pm 0.07$ & $41.22^{\mathrm{i}} \pm 0.37$ & $10.77^{b} \pm 0.01$ & $52.35^{\mathrm{a}} \pm 10.83$ \\
\hline NFC1 & $41.67^{\mathrm{d}} \pm 0.31$ & $15.16^{\mathrm{f}} \pm 0.01$ & $58.33^{\mathrm{f}} \pm 0.31$ & $39.54^{\mathrm{c}} \pm 0.44$ & $15.50^{\mathrm{f}} \pm 0.01$ & $60.19^{\mathrm{e}} \pm 0.23$ & $31.22^{\mathrm{e}} \pm 0.35$ & $15.08^{\mathrm{e}} \pm 0.02$ & $68.78^{\mathrm{e}} \pm 0.35$ \\
\hline NFC2 & $42.23^{\mathrm{d}} \pm 0.30$ & $14.00^{\mathrm{e}} \pm 0.02$ & $57.59^{\mathrm{f}} \pm 0.40$ & $39.05^{\mathrm{c}} \pm 0.23$ & $14.08^{\mathrm{e}} \pm 0.20$ & $60.95^{\mathrm{f}} \pm 0.23$ & $28.66^{\mathrm{d}} \pm 0.61$ & $13.74^{\mathrm{d}} \pm 0.02$ & $71.34^{\mathrm{f}} \pm 0.61$ \\
\hline NFC3 & $43.89^{\mathrm{e}} \pm 0.08$ & $43.89^{j} \pm 0.08$ & $56.11^{\mathrm{e}} \pm 0.08$ & $40.34^{\mathrm{d}} \pm 0.38$ & $40.13^{\mathrm{i}} \pm 0.06$ & $59.87^{\mathrm{e}} \pm 0.06$ & $32.80^{\mathrm{f}} \pm 1.17$ & $32.80^{\mathrm{i}} \pm 1.17$ & $66.96^{\mathrm{d}} \pm 1.02$ \\
\hline AFC1 & $32.92^{\mathrm{c}} \pm 0.63$ & $32.92^{\mathrm{i}} \pm 0.63$ & $67.08^{g} \pm 0.63$ & $30.79^{\mathrm{a}} \pm 0.72$ & $30.79^{\mathrm{g}} \pm 0.72$ & $69.21^{\mathrm{h}} \pm 0.72$ & $27.20^{\mathrm{b}} \pm 0.22$ & $27.20^{\mathrm{g}} \pm 0.22$ & $72.80^{\mathrm{f}} \pm 0.22$ \\
\hline $\mathrm{AFC} 2$ & $31.13^{\mathrm{a}} \pm 0.07$ & $32.03^{\mathrm{h}} \pm 0.17$ & $66.67^{g} \pm 0.32$ & $33.00^{\mathrm{b}} \pm 0.73$ & $33.33^{\mathrm{h}} \pm 0.32$ & $68.87^{\mathrm{h}} \pm 0.07$ & $24.53^{\mathrm{a}} \pm 0.09$ & $24.53^{\mathrm{f}} \pm 0.08$ & $75.47^{\mathrm{g}} \pm 0.09$ \\
\hline AFC3 & $32.03^{\mathrm{a}} \pm 0.16$ & $32.03^{\mathrm{h}} \pm 0.17$ & $69.44^{\mathrm{h}} \pm 0.52$ & $30.33^{\mathrm{a}} \pm 0.15$ & $30.33^{\mathrm{h}} \pm 0.15$ & $67.97^{\mathrm{g}} \pm 0.17$ & $26.61^{b} \pm 0.09$ & $26.61^{g} \pm 0.09$ & $73.39^{\mathrm{g}} \pm 0.09$ \\
\hline NPK & $47.58^{\mathrm{f}} \pm 0.52$ & $1.27^{\mathrm{a}} \pm 0.02$ & $52.42^{\mathrm{d}} \pm 0.52$ & $44.84^{\mathrm{f}} \pm 0.85$ & $1.19^{\mathrm{a}} \pm 0.01$ & $55.16^{\mathrm{c}} \pm 0.09$ & $33.99^{\mathrm{g}} \pm 0.02$ & $1.08^{\mathrm{a}} \pm 0.03$ & $66.01^{\mathrm{d}} \pm 0.02$ \\
\hline
\end{tabular}


Table 3. The phosphorus content $(\mathrm{mg} / \mathrm{kg})$, percentage of nitrogen content and $\mathrm{pH}$ of the compost samples.

\begin{tabular}{cccccccc}
\hline $\begin{array}{c}\text { Mesh size } \\
\text { Samples }\end{array}$ & $\begin{array}{c}150 \mu \mathrm{m} \% \\
\text { Nitrogen }\end{array}$ & $\begin{array}{c}150 \mu \mathrm{m} \\
\text { Phosphorus }\end{array}$ & $\begin{array}{c}212 \mu \mathrm{m} \% \\
\text { Nitrogen }\end{array}$ & Phosphorus & $\begin{array}{c}425 \mu \mathrm{m} \% \\
\text { Nitrogen }\end{array}$ & Phosphorus & $\mathrm{pH}$ \\
\hline $\mathrm{UC}$ & $1.62^{\mathrm{a}} \pm 0.01$ & $351.17^{\mathrm{b}} \pm 0.76$ & $1.58^{\mathrm{a}} \pm 0.01$ & $336.11^{\mathrm{a}} \pm 0.96$ & $1.28^{\mathrm{a}} \pm 0.08$ & $329.10^{\mathrm{b}} \pm 0.21$ & $10.35^{\mathrm{h}} \pm 0.03$ \\
$\mathrm{KFC}_{1}$ & $2.65^{\mathrm{c}} \pm 0.02$ & $720.65^{\mathrm{a}} \pm 0.02$ & $2.21^{\mathrm{b}} \pm 0.03$ & $712.21^{\mathrm{a}} \pm 0.03$ & $2.00^{\mathrm{b}} \pm 0.01$ & $702.00^{\mathrm{a}} \pm 0.01$ & $9.88^{\mathrm{g}} \pm 0.01$ \\
$\mathrm{KFC}_{2}$ & $2.55^{\mathrm{b}} \pm 0.01$ & $796.95^{\mathrm{g}} \pm 0.92$ & $2.46^{\mathrm{c}} \pm 0.01$ & $772.91^{\mathrm{a}} \pm 0.25$ & $2.23^{\mathrm{c}} \pm 0.1$ & $733.06^{\mathrm{h}} \pm 0.06$ & $9.78^{\mathrm{f}} \pm 0.02$ \\
$\mathrm{KFC}_{3}$ & $2.54^{\mathrm{b}} \pm 0.02$ & $803.83^{\mathrm{h}} \pm 0.21$ & $9.80^{\mathrm{g}} \pm 0.00$ & $725.97^{\mathrm{a}} \pm 1.20$ & $2.23^{\mathrm{c}} \pm 0.01$ & $707.06^{\mathrm{g}} \pm 0.07$ & $9.86^{\mathrm{f}} \pm 0.01$ \\
$\mathrm{NFC}_{1}$ & $3.69^{\mathrm{d}} \pm 0.01$ & $750.59^{\mathrm{f}} \pm 0.36$ & $3.54^{\mathrm{d}} \pm 0.01$ & $686.84^{\mathrm{b}} \pm 0.92$ & $3.28^{\mathrm{d}} \pm 0.03$ & $595.75^{\mathrm{f}} \pm 0.26$ & $7.19^{\mathrm{e}} \pm 0.02$ \\
$\mathrm{NFC}_{2}$ & $3.70^{\mathrm{d}} \pm 0.01$ & $274.06^{\mathrm{i}} \pm 0.23$ & $3.51^{\mathrm{d}} \pm 0.03$ & $217.20^{\mathrm{d}} \pm 0.31$ & $3.22^{\mathrm{d}} \pm 0.03$ & $203.31^{\mathrm{i}} \pm 0.09$ & $7.18^{\mathrm{e}} \pm 0.01$ \\
$\mathrm{NFC}_{3}$ & $3.72^{\mathrm{d}} \pm 0.02$ & $277.27 \pm 0.333$ & $3.52^{\mathrm{d}} \pm 0.05$ & $248.43^{\mathrm{d}} \pm 0.41$ & $3.29^{\mathrm{d}} \pm 0.09$ & $223.28^{\mathrm{j}} \pm 0.33$ & $7.20^{\mathrm{e}} \pm 0.02$ \\
$\mathrm{AFC}_{1}$ & $5.03 \pm 0.06$ & $287.69^{\mathrm{k}} \pm 0.62$ & $4.81^{\mathrm{f}} \pm 0.01$ & $267.85^{\mathrm{d}} \pm 0.32$ & $4.59^{\mathrm{f}} \pm 0.01$ & $226.57^{\mathrm{j}} \pm 0.14$ & $6.65^{\mathrm{c}} \pm 0.02$ \\
$\mathrm{AFC}_{2}$ & $5.62^{\mathrm{g}} \pm 0.03$ & $536.03^{\mathrm{c}} \pm 0.16$ & $5.42^{\mathrm{g}} \pm 0.01$ & $501.10^{\mathrm{c}} \pm 0.27$ & $5.26^{\mathrm{g}} \pm 0.01$ & $451.39^{\mathrm{d}} \pm 1.55$ & $6.29^{\mathrm{b}} \pm 0.02$ \\
$\mathrm{AFC}_{3}$ & $4.28^{\mathrm{e}} \pm 0.03$ & $555.23^{\mathrm{d}} \pm 0.86$ & $4.07^{\mathrm{e}} \pm 0.02$ & $511.59^{\mathrm{c}} \pm 0.47$ & $3.90^{\mathrm{e}} \pm 0.02$ & $426.34^{\mathrm{c}} \pm 0.78$ & $6.94^{\mathrm{d}} \pm 0.04$ \\
$\mathrm{NPK}$ & $79.35^{\mathrm{h}} \pm 0.06$ & $610.31^{\mathrm{e}} \pm 0.01$ & $76.03^{\mathrm{h}} \pm 0.05$ & $563.58^{\mathrm{c}} \pm 0.61$ & $73.28^{\mathrm{h}} \pm 0.02$ & $537.41^{\mathrm{e}} \pm 12.50$ & $5.76^{\mathrm{a}} \pm 0.14$ \\
\hline
\end{tabular}

Results represent mean of three replicates $( \pm \mathrm{SD})$ of mineral analysis in the compost samples (mg/kg concentration).

Table 4. (a) Compost samples sieved using the mesh size $150 \mu \mathrm{m}$; (b) Compost samples sieved using the mesh size $212 \mu \mathrm{m}$; (c) Compost samples sieved using the mesh size $425 \mu \mathrm{m}$.

(a)

\begin{tabular}{cccccccccccc}
\hline Sample & $\mathrm{K}$ & $\mathrm{Ni}$ & $\mathrm{Zn}$ & $\mathrm{Co}$ & $\mathrm{Cu}$ & $\mathrm{Pb}$ & $\mathrm{Fe}$ & $\mathrm{Mn}$ & $\mathrm{Na}$ & $\mathrm{Ca}$ & $\mathrm{Mg}$ \\
\hline $\mathrm{UC}$ & 427.56 & - & 1.68 & 0.55 & & & 0.84 & 78.00 & 355.42 & 397.14 & 344.06 \\
$\mathrm{KFC}$ & 340.77 & - & 1.30 & - & 0.04 & 0.83 & 0.82 & 34.15 & 377.82 & 432.66 & 366.68 \\
$\mathrm{NFC}$ & 328.06 & - & 5.23 & 1.75 & 0.04 & 0.56 & 1.64 & 183.48 & 267.74 & 292.00 & 359.15 \\
$\mathrm{AFC}$ & 253.01 & - & 2.43 & 0.55 & 0.45 & 0.83 & 1.64 & 46.64 & 268.17 & 245.40 & 348.30 \\
$\mathrm{NPK}$ & 2050 & 2.05 & 1.54 & 4.49 & 3.46 & 28.90 & 4.56 & 24.37 & 90 & 10695.81 & 361.85 \\
\hline
\end{tabular}

(b)

\begin{tabular}{ccccccccccc}
\hline Sample & $\mathrm{K}$ & $\mathrm{Ni}$ & $\mathrm{Zn}$ & $\mathrm{Co}$ & $\mathrm{Cu}$ & $\mathrm{Fe}$ & $\mathrm{Na}$ & $\mathrm{Ca}$ & $\mathrm{Mg}$ \\
\hline $\mathrm{UC}$ & 273.72 & - & - & - & - & 8.19 & 336.11 & 353.52 & 342.17 \\
$\mathrm{KFC}$ & 267.97 & - & - & - & - & - & 251.23 & 292.96 & 351.95 \\
$\mathrm{NFC}$ & 233.73 & - & 3.83 & 0.65 & - & 0.72 & 207.74 & 215.90 & 341.51 \\
$\mathrm{AFC}$ & 225.06 & - & 0.75 & - & - & 0.82 & 208.60 & 205.23 & 338.65 \\
$\mathrm{NPK}$ & 2050 & 2.05 & 1.54 & 4.49 & 3.46 & 4.56 & 90 & 10695.81 & 361.85 \\
\hline
\end{tabular}

(c)

\begin{tabular}{ccccccccccccc}
\hline Samples & $\mathrm{K}$ & $\mathrm{Ni}$ & $\mathrm{Zn}$ & $\mathrm{Co}$ & $\mathrm{Cu}$ & $\mathrm{Pb}$ & $\mathrm{Fe}$ & $\mathrm{Mn}$ & $\mathrm{Na}$ & $\mathrm{Ca}$ & $\mathrm{Mg}$ \\
\hline $\mathrm{UC}$ & 251.35 & - & - & - & - & - & 3.27 & 27.44 & 31.68 & 316.51 & 337.37 \\
$\mathrm{KFC}$ & 168.04 & - & - & - & - & - & - & - & 214.44 & 325.33 & 340.68 \\
$\mathrm{NFC}$ & 186.61 & - & 2.05 & - & - & - & - & 56.36 & 149.35 & 191.88 & 316.81 \\
$\mathrm{AFC}$ & 151.55 & - & - & - & - & - & - & 13.09 & 184.26 & 173.84 & 323.17 \\
$\mathrm{NPK}$ & 2050 & 2.05 & 1.54 & 4.49 & 3.46 & 28.90 & 4.56 & 24.37 & 90.0 & 10695.81 & 361.85 \\
\hline
\end{tabular}


seen that the finer the size of the compost particles the higher the value of the organic and mineral nutrients present, it means that finished compost samples must be grounded before application. This also will help to overcome the most disadvantage of organic fertilizer which is the slow release of nutrients.

\section{REFERENCES}

[1] Berwick, M.W.M. (1980) Handbook of organic waste conversion. Van Nostrand Reinhold, Wokingham.

[2] Akanbi, W.B., Olaniran, O.A., Olaniyi, M.A. and Sanusi, O.O. (2007) Effect of cassava peel compost on growth and nutritional quality of celosia (Celosia argentea L.). Research Journal of Agronomy, 1, 110-115.

[3] Salisbury, F.B. and Ross, C. (1969) Plant physiology. Wadsworth Publishing Co., Inc., Belmont.

[4] Neemat, M.A. and Khaled, S.M. (2012) Maximizing effect of mineral fertilizers compost and biofortified compost. Australian Journal of Basic and Applied Sciences, 6, 482-493.

[5] Rizwan, A., Sher, M.S., Azeem, K., Muhammad, A. and Muhammad, H.M. (2007) Growth and yield response of wheat (Triticum aestivum L.) and maize (Zea mays L.) to nitrogen and L-Tryptophan enriched compost. Pakistan Journal of Botany, 39, 541-549.
[6] Daramola, D.S., Ogunnowo, A.A., Aina, D.A., Olawuyi, O.J., Agbolade, J.O. and Nwadike, J.C. (2011) Maize (Zea mays L.) growth and tissue response to organic manure and its mineral-nitrogen fortifications. Scholarly Journal of Agricultural Science, 1, 47-54.

[7] A.O.A.C. (1990) Official Method of Analysis. 15th Edition, Association of Official Analytical Chemists, Washington DC.

[8] Pearson, D. (1981) The chemical analysis of foods. 6th Edition, J. \& A. Churchill, Ltd., London.

[9] Ibitoye, A.A. (2006) Laboratory manual on basic soil analysis. Foladave Publishers, Akure.

[10] Pomeranz, Y. and Meloan, C.E. (1987) Food analysis: Theory and practice. 2nd Edition, Van Nostrand Reinhold, New York.

[11] Relf, P.D. (1990) The Virginia master gardener handbook. Virginia Cooperative Extension Services, Blacksburg.

[12] Simmons, J. (1998) Earthworks and organic products balancing soil nutrition. Turnstile Publishing Company, Orlando.

[13] Ayoola, O.T. and Makinde E.A. (2008) Performance of green maize and soil nutrient changes is fortified cow dump. African Journal of Plant Science, 2, 19-22. 